\title{
What do different landscapes of the Atlantic Forest reveal about the occurrence of Discothyrea Roger, 1863 (Formicidae: Proceratiinae)?
}

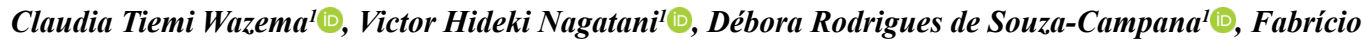 \\ Severo Magalhães ${ }^{1}\left(\mathbb{D}\right.$, Ricardo Sartorello $^{2}$ \& Maria Santina de Castro Morini ${ }^{1}$ *(1) \\ ${ }^{1}$ Universidade Mogi das Cruzes, Laboratório de Mirmecologia do Alto Tietê, Núcleo de Ciências Ambientais, \\ Centro Cívico, Av. Dr. Cândido Almeida e Souza, $n^{\circ}$ 200, CEP 08780-911, Mogi das Cruzes, SP, Brasil. \\ ${ }^{2}$ Universidade de Mogi das Cruzes, Laboratório de Mapeamento e Análise da Paisagem, Núcleo de Ciências \\ Ambientais, Av. Dr. Cândido Xavier de Almeida de Souza, n²00, CEP 08780-911, Mogi das Cruzes, SP, Brasil. \\ *Corresponding author: Maria Santina de Castro Morini, e-mail: mscmorini@gmail.com
}

WAZEMA, C.T., NAGATANI, V.H., SOUZA-CAMPANA, D.R., MAGALHÃES, F.S., SARTORELLO, R., MORINI, M.S.C. What do different landscapes of the Atlantic Forest reveal about the occurrence of Discothyrea Roger, 1863 (Formicidae: Proceratiinae)? Biota Neotropica 20(4): e20201035. https://doi.org/10.1590/1676-0611-BN-2020-1035

\begin{abstract}
Discothyrea is a genus composed of specialist predatory species rarely recorded and with little known biology. Specimen collection is usually associated with preserved native vegetation. In this work, we explore the landscape of sites with occurrence of Discothyrea seeking to improve knowledge about the natural history of this genus. Species of Discothyrea were recorded in ten Atlantic Forest sites. We analyzed the landscape around the place of occurrence of each species using a 500-m buffer. We classified the landscape as heterogeneous and homogeneous according to the percentage of natural (native vegetation), urban, and rural areas. We found 67 specimens of Discothyrea; 59 of them were D. sexarticulata, occurring in $88 \%$ of the fragments. There were also eight specimens of $D$. neotropica occurring in $12 \%$ of the fragments. The results show that $D$. sexarticulata can be found in homogeneous landscapes with anthropic influence $(0-51 \%$ of rural area and $0-68 \%$ of urban area). Discothyrea neotropica is found in heterogeneous landscapes with a dominant presence of native vegetation (between 74-95\%). The results improve knowledge on the biology of Discothyrea mainly in relation to the vicinity of occurrence sites. In addition, the results indicate that regional studies are important to understand species ecology. Keywords: Hypogeic species; mosaic of landscapes; cryptic habit; conservation.
\end{abstract}

\section{O que diferentes paisagens da Floresta Atlântica nos mostram sobre a ocorrência de Discothyrea Roger, 1863 (Formicidae: Proceratiinae)?}

Resumo: Discothyrea é um gênero composto por espécies predadoras especialistas, raramente registradas e com biologia pouca conhecida. A coleta de espécimes geralmente está associada à vegetação nativa preservada. Neste trabalho exploramos a paisagem de locais com ocorrência de Discothyrea, buscando incrementar o conhecimento sobre a história natural do gênero. Espécies de Discothyrea foram registradas em dez áreas de Mata Atlântica. A paisagem ao redor do local de ocorrência de cada espécie foi analisada, usando um buffer de $500 \mathrm{~m}$. Classificamos a paisagem em heterogênea e homogênea de acordo com a porcentagem de área natural (vegetação nativa), urbana e rural. Encontramos 67 espécimes de Discothyrea; 59 de D. sexarticulata, em $88 \%$ dos fragmentos. E oito espécimes de $D$. neotropica, em $12 \%$ dos fragmentos. Nossos resultados mostram que $D$. sexarticulata pode ser encontrada em paisagens homogêneas e sob influência antrópica, com 0-51\% de área rural e 0-68\% de área urbana; e D. neotropica em paisagens heterogêneas, com presença dominante de vegetação nativa (entre 74-95\%). Nossos resultados trazem um aporte de conhecimento à biologia de Discothyrea, principalmente em relação às adjacências do local de ocorrência. Além disso, nossos resultados indicam que estudos regionais são importantes ferramentas para o conhecimento da ecologia das espécies.

Palavras-chave: Espécie hipogeica; mosaico de paisagens; hábito críptico; conservação. 


\section{Introduction}

The genus Discothyrea Roger, 1863, has 50 species distributed in tropical areas of the southern hemisphere. The occurrence area extends from the midwestern and southeastern United States to northern Argentina. It is found mainly in the Neotropical Region, especially in tropical forest areas (Antweb 2020, Antwiki 2020). There are eight species recorded in the Neotropical Region (Sosa-Calvo \& Longino 2007, Antmaps 2020), five in Brazil [Discothyrea denticulata Weber, 1939, D. horni Menozzi, 1927, D. humilis Weber, 1939, D. sexarticulata Borgmeier, 1954 and D. neotropica Bruch, 1919], and two in the State of São Paulo [D. sexarticulata and D. neotropica (Delabie et al. 2015, Antmaps 2020)].

The species are considered rare in litter probably because (1) the colonies have few individuals (Dejean \& Dejean 1998, Katayama 2013, Delabie et al. 2015), (2) there is a limitation of sampling techniques (Hita- Garcia et al. 2019), and (3) the workers are very small, between 0.2 and $0.5 \mathrm{~mm}$ (Brandão et al. 2009). The species have a cryptic habit and the nests are generally inconspicuous (Zacharias \& Dharma Rajan 2004), located in litter interstices, decaying logs (Brown 1958; Delabie et al. 2015), and under rocks (Bharti et al. 2015). Twigs from the fragmentation of tree branches are important for many ant species, especially for nesting. However, it is probably not a type of resource used by Discothyrea species in litter (see Fernandes et al. 2019a, b; 2020).

The species are specialist predators feeding almost exclusively on arthropod eggs, especially centipedes and spiders (Brown 1957, 1958, Dejean et al. 1999, Baccaro et al. 2015), but also on Tenebrio molitor Linnaeus, 1758, larvae (Wazema, personal communication). Discothyrea specimens can be collected in leaf litter using pitfall traps (Morini et al. 2007) and mainly in samples of leaf litter in forests with different phytophysiognomies (Vasconcelos \& Delabie 2000, Feitosa \& Ribeiro 2005, Suguituru et al. 2013, Wazema et al. 2019) and at different altitudes (Santos 2008). There are records in Pinus elliottii (Pachedo et al. 2009) and eucalyptus crops (Mentone et al. 2011, Suguituru et al. 2011), but these sites were surrounded by native vegetation. Lassau \& Hocholi (2004) analyzed the response of ant communities to various physical and biological factors that occur in undisturbed places and recorded species of Discothyrea in low- and high-complexity habitats. In fragments of Atlantic Forest in the state of São Paulo, records of Discothyrea spp. are usually associated to preserved native vegetation (Suguituru et al. 2013, 2015).

The Brazilian Atlantic Forest has been reduced to immense archipelagos of tiny and widely separated forest fragments (Joly et al. 2014). Moreover, urban areas surround most fragments (Tabarelli et al. 2005), as well as areas with other anthropogenic activities (Ribeiro et al. 2009), such as extensive agriculture areas and eucalyptus and sugarcane crops. In a natural environment, changes caused by different land uses alter the landscape structure (e.g., by loss of biotic and abiotic resources), which in turn affect ant communities (Crist 2009). Ants are important components of the edaphic fauna (Decaëns 2010). They are considered good ecological indicators (Ribas et al. 2012, Casimiro et al. 2019), as their communities are influenced both on a local and a regional scale (Spiesman \& Cumming 2008, Cumming 2011). Smaller and isolated fragments are more susceptible to species extinction and invasion by generalist species (Schoereder et al. 2004).
Generalist species affect habitats in sites with high proportions of matrix habitats in the surrounding landscape (Spiesman \& Cumming 2008).

As the structure of vegetation and soil and related abiotic factors influence ant communities, the analysis of landscape fragments and their surroundings may help the implementation of conservation management plans or environmental planning (Lindenmayer et al. 2008, László et al. 2014). This is true especially when species are considered rare, as they play a fundamental role in the evolutionary adaptation of communities to changing land uses (László et al. 2014). In this work, we evaluated the landscape in the vicinity of Discothyrea occurrence sites seeking to fill gaps in knowledge about the biology of this genus. We hope to find Discothyrea in fragments of the Atlantic Forest surrounded mainly by native vegetation, as Discothyrea species are considered rare and specialized.

\section{Materials and Methods}

This study was conducted in ten sites in the following cities: São Paulo (Previdência Park), Mogi das Cruzes (Kimberly-Clark Reserve, Francisco Affonso de Mello Municipal Natural Park, Private Natural Heritage Reserve - Botujuru, and Leon Feffer Park), Mogi das Cruzes/Bertioga (Neblinas Park), Biritiba-Mirim (BiritibaMirim Dam), and Salesópolis (Ponte Nova Dam, Paraitinga Dam, and Ribeirão do Campo Dam) (Figure 1). All sites are part of the Atlantic Forest Domain in Southeast Brazil (Fiaschi \& Pirani 2009, Colombo \& Joly 2010). According to the Köppen classification, the region's climate is mesothermal with dry winters $(\mathrm{Cwb})$. The annual rainfall accumulation is $1,500 \mathrm{~mm}$ (Cptec-Inpe 2020).

Ants were collected on the litter between 2001 and 2019 using techniques such as mini-Winkler extractors (Suguituru et al. 2013, Wazema et al. 2019) and pitfalls (Morini et al. 2007). The identification was carried out using keys specific to this group (Borgmeier 1949, Fernández 2003, Jiménez et al. 2008, Eguchi et al. 2014, Xu et al. 2014, Bharti et al. 2015) and by comparison with specimens deposited at the Reference Collection of the Alto Tietê Myrmecology Laboratory (LAMAT-UMC) (Suguituru et al. 2015) of the University of Mogi das Cruzes, São Paulo, Brazil, where the vouchers of this work are deposited.

The landscape was characterized using a 500-m buffer for each species occurrence site (Figure 1). Each collection period has its own methods. Aerial images were obtained using the Landsat 8 Satellite (Bing aerial - Bing 2020 Microsoft Corporation Earthstar Geographics SIO, ${ }^{\circ}$ Microsoft Corporation). Each buffer $(n=10)$ was categorized in (1) native vegetation, (2) rural, and (3) urban areas. Each class was quantified in $\mathrm{m}^{2}$. The landscape of the surroundings of each collection site was classified as heterogeneous [area of native vegetation $\geq 50 \%$ (Figure 2a)] and homogeneous area [percentage of rural and urban areas $\geq 50 \%$ (Figure 2b)] (Moreira et al. 2015). The scale was 1:3,000. The software QGIS, version 2.18.19, was used (QGIS Development Team 2018). The linear models (GLM) with Poisson distribution (software R) were used to test differences in species occurrence among areas. The analyses were performed using the software Rstudio (R, version 3.6.1, R Core Team 2019) at a 5\% significance level. 


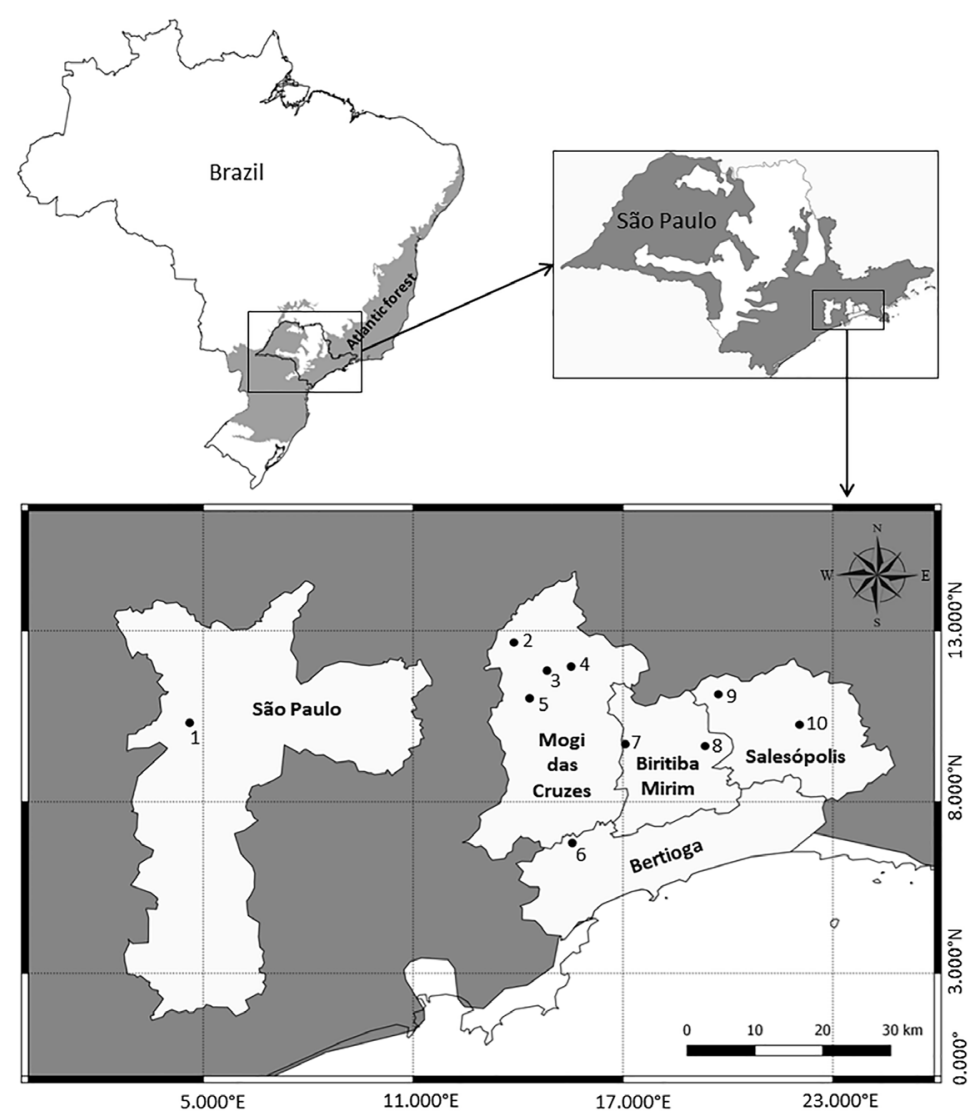

Figure 1. Location of collection sites. 1 - Previdência Park, 2 - Kimberly-Clark Reserve, 3 - Francisco Affonso de Mello Municipal Natural Park, 4 - Private Natural Heritage Reserve - Botujuru, 5 - Leon Feffer Park, 6 - Neblinas Park, 7 - Biritiba-Mirim Dam, 8 - Ponte Nova Dam, 9 - Paraitinga Dam, and 10 - Ribeirão do Campo Dam.

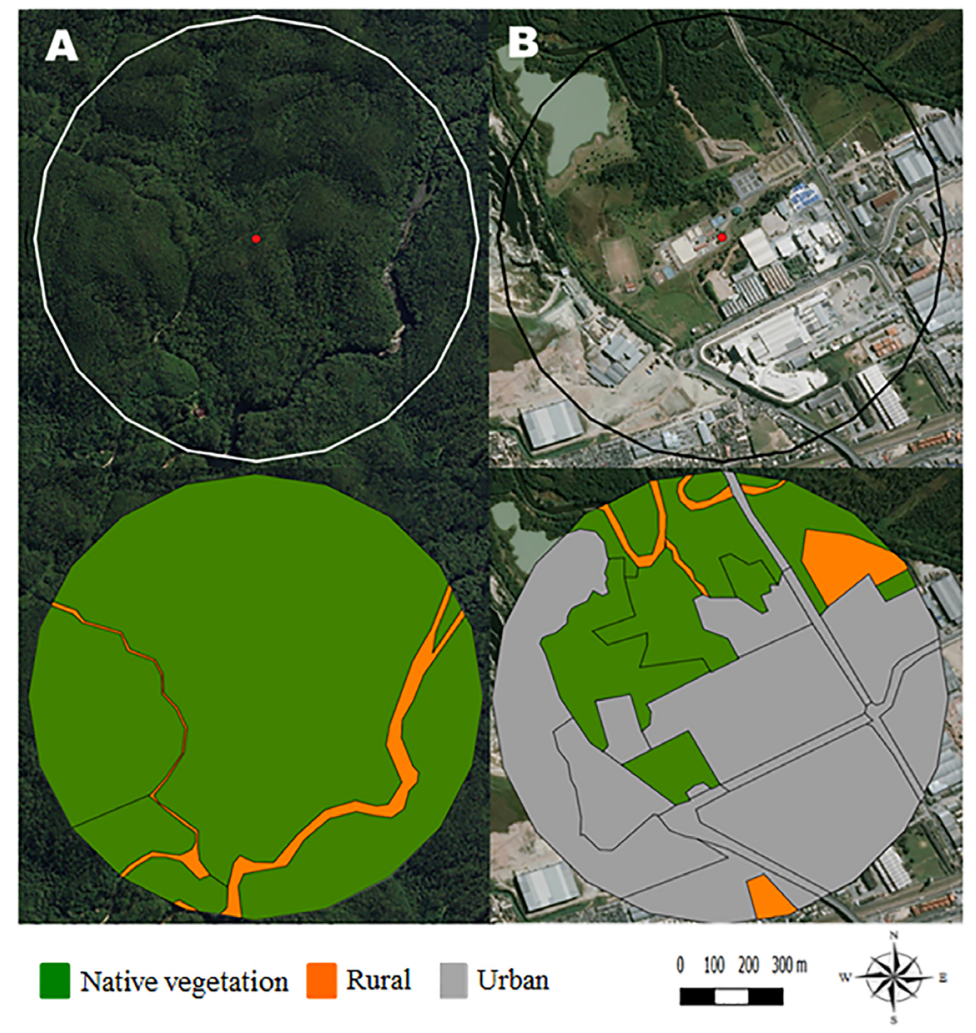

Figure 2. Characterization of the $500 \mathrm{~m}$ buffer and classes of the location where the species were collected. a - heterogeneous landscape (Neblinas Park, São Paulo city); and $\mathrm{b}$ - homogeneous landscape (Leon Feffer Park, São Paulo city). 


\section{Results and Discussion}

The results show that $D$. sexarticulata is more common than $D$. neotropica in the Atlantic Forest areas of the São Paulo state. We collected 67 specimens belonging to the Discothyrea. Discothyrea sexarticulata (59 specimens) occurred in $88 \%$ of the sites, and $D$. neotropica (eight specimens) occurred in $12 \%$ (Table 1). This is probably due to the resilience of $D$. sexarticulata. The data also show that this species occurs in fragments where the surroundings have $27-92 \%$ of native vegetation, $0-51 \%$ of rural areas, and $0-68 \%$ of urban areas (Table 1). We thus suggest that D. sexarticulata inhabits fragments with heterogeneous surroundings comprising a higher percentage of native and homogeneous vegetation and where anthropogenic changes (e.g., urban areas and crops) are more marked. In contrast, $D$. neotropica was recorded in fragments with more preserved surroundings, with $74-95 \%$ of native vegetation, $5-26 \%$ of rural areas, and $0-1 \%$ of urban areas (Table 1). The results suggest that this species occurs in fragments of the Atlantic Forest with a heterogeneous adjacency and a higher percentage of native Atlantic Forest vegetation. However, Arcusa \& Cicchino (2017) reported that
D. neotropica also inhabits pastures in the Pampas Region, which are considered areas of low environmental complexity.

The species of Discothyrea are tiny and its eyes have only one ommatid (Brandão et al. 2009, Delabie et al. 2015). These characteristics and the presence of small legs (Brandão et al. 2009) should limit mobility to small extensions (Yates \& Andrew 2011). Therefore, the location where the nest is found should be relevant to these species, especially a location with a greater variety of interstices (e.g., litter), which contributes to less energy expenditure during foraging (Kaspari $\&$ Weiser 1999). Adjacent areas must affect the fragment's temperature and humidity (Lima-Ribeiro 2008), especially in areas considered small (Magnago et al. 2015). Changes in the natural environment can affect Discothyrea species at (1) a local scale, where the lack of humidity is a limiting factor for small species that forage in interstices of leaf litter (Kaspari 1996), and (2) a landscape scale, as landscape changes affect rare species more than common species (László et al. 2014). In this context, we suggest that $D$. sexarticulata may be less sensitive to changes than $D$. neotropica. However, the results of the analyses (Table 2) show that a larger number of samples is necessary, especially of $D$. sexarticulata.

Table 1. Collection site, landscape composition, and number of specimens according to Discothyrea species.

\begin{tabular}{|c|c|c|c|c|c|c|c|c|c|}
\hline \multirow[t]{2}{*}{ Sites } & \multirow[t]{2}{*}{$\begin{array}{c}\text { Sites } \\
\text { characterization }\end{array}$} & \multicolumn{2}{|c|}{ Coordenates } & \multicolumn{3}{|c|}{$\begin{array}{c}\text { Landscape composition } \\
(\%)\end{array}$} & \multirow[t]{2}{*}{$\begin{array}{l}\text { Landscape } \\
\text { types }\end{array}$} & \multicolumn{2}{|c|}{ Number of specimens } \\
\hline & & Latitude & Longitude & $\begin{array}{c}\text { Native } \\
\text { vegetation }\end{array}$ & $\begin{array}{c}\text { Rural } \\
\text { area }\end{array}$ & $\begin{array}{l}\text { Urban } \\
\text { area }\end{array}$ & & $\begin{array}{c}\text { D. } \\
\text { neotropica }\end{array}$ & $\begin{array}{c}\text { D. } \\
\text { sexarticulata }\end{array}$ \\
\hline 1-Previdência Park & Urban park & $23^{\circ} 34^{\prime} 00^{\prime \prime S}$ & $46^{\circ} 43^{\prime} 00^{\prime \prime} \mathrm{W}$ & 37 & 0 & 63 & Homogeneous & - & 1 \\
\hline $\begin{array}{l}\text { 2-Kimberly-Clark } \\
\text { Reserve }\end{array}$ & $\begin{array}{c}\text { Anthropized } \\
\text { fragment of } \\
\text { Atlantic Forest }\end{array}$ & $23^{\circ} 262^{\prime \prime} \mathrm{S}$ & $46^{\circ} 14^{\prime} 48^{\prime \prime} \mathrm{W}$ & 59 & 8 & 33 & Heterogeneous & - & 9 \\
\hline $\begin{array}{l}\text { 3-Francisco Affonso } \\
\text { de Mello Municipal } \\
\text { Natural Park }\end{array}$ & $\begin{array}{l}\text { Conservation } \\
\text { units }\end{array}$ & $23^{\circ} 29^{\prime} 22^{\prime \prime S}$ & $46^{\circ} 11^{\prime} 55^{\prime \prime} \mathrm{W}$ & 92 & 8 & 0 & Heterogeneous & - & 1 \\
\hline $\begin{array}{l}\text { 4-Private Natural } \\
\text { Heritage Reserve - } \\
\text { Botujuru }\end{array}$ & $\begin{array}{l}\text { Conservation } \\
\text { units }\end{array}$ & $23^{\circ} 28^{\prime} 59^{\prime \prime} \mathrm{S}$ & $46^{\circ} 09^{\prime} 49^{\prime \prime} \mathrm{W}$ & 49 & 51 & 0 & Homogeneous & - & 21 \\
\hline 6-Neblinas Park & $\begin{array}{c}\text { Conserved } \\
\text { Atlantic Forest } \\
\text { area }\end{array}$ & $23^{\circ} 44^{\prime} 40^{\prime \prime S}$ & $46^{\circ} 09^{\prime} 43^{\prime \prime} \mathrm{W}$ & 95 & 5 & 0 & Heterogeneous & 5 & 3 \\
\hline 7-Biritiba Mirim Dam & $\begin{array}{l}\text { Conserved } \\
\text { Atlantic Forest } \\
\text { fragment }\end{array}$ & $23^{\circ} 35^{\prime} 54^{\prime \prime} \mathrm{S}$ & $46^{\circ} 05^{\prime} 06^{\prime \prime} \mathrm{W}$ & 74 & 26 & 0 & Heterogeneous & - & 4 \\
\hline 8-Ponte Nova Dam & $\begin{array}{l}\text { Conserved } \\
\text { Atlantic Forest } \\
\text { fragment }\end{array}$ & $23^{\circ} 36^{\prime} 04^{\prime \prime S}$ & $45^{\circ} 58^{\prime} 10^{\prime \prime} \mathrm{W}$ & 80 & 19 & 1 & Heterogeneous & - & 14 \\
\hline 9-Paraitinga Dam & $\begin{array}{l}\text { Conserved } \\
\text { Atlantic Forest } \\
\text { fragment }\end{array}$ & $23^{\circ} 31^{\prime} 28^{\prime \prime S}$ & $45^{\circ} 57^{\prime} 01^{\prime \prime} \mathrm{W}$ & 51 & 49 & 0 & Heterogeneous & 2 & 4 \\
\hline
\end{tabular}


Occurrence of Discothyrea

Table 2. Summary of GLM with a transect-level random intercept (ten transects, one in each area). Landscape classes selected according to landscape composition (\%) of areas: NV-U (Native vegetation + urban area), NV-R-U (Native vegetation + rural area + urban area) and NV-R (Native vegetation + rural area).

\begin{tabular}{|c|c|c|c|c|}
\hline \multicolumn{5}{|c|}{ Model: Occurrence of $D$. sexarticulata $\sim$ Area $+(1 \mid$ transect $)$} \\
\hline Predictors & Estimated & Standard Error & $\mathrm{Z}$ & $p$ \\
\hline Intercept & -2.438 & 1.000 & 0.000 & 1.000 \\
\hline NV-R-U & 1.846 & 1.026 & 1.799 & 0.072 \\
\hline NV-R & 1.482 & 1.022 & 1.449 & 0.147 \\
\hline Predictors & Estimated & Standard Error & $\mathrm{Z}$ & $p$ \\
\hline Intercept & -1.830 & 5.718 & -0.003 & 0.997 \\
\hline $\mathrm{NV}-\mathrm{U}$ & -4.912 & 8.086 & 0.000 & 1.000 \\
\hline NV-R-U & 1.790 & 5.718 & 0.003 & 0.998 \\
\hline NV-R & 1.848 & 5.718 & 0.003 & 0.997 \\
\hline
\end{tabular}

Therefore, this study significantly contributes to the knowledge on the biology of Discothyrea. There are few studies on the natural history and behavior of species of this genus possibly because they have cryptic habits and small sizes. The results show that $D$. sexarticulata and $D$. neotropica occur in fragments with different surroundings, suggesting a greater resilience of $D$. sexarticulata. Our study indicates that landscape scales can be important structuring forces on local communities. We report relevant technical knowledge for future studies on landscape ecology and ant communities in Atlantic Forest areas. Furthermore, we demonstrate the importance of regional studies as a tool for understanding species ecology. As most of the Atlantic Forest is composed of forest fragments smaller than 50 ha (Ribeiro et al. 2009), corresponding to vegetation islands within a matrix with several types of anthropogenic activity (e.g., crops, paved roads, dense buildings, railroads, and mining), studies of this nature are highly relevant for the conservation of species.

\section{Acknowledgements}

We would like to thank Kimberly-Clark for funding the Scientific Initiation Scholarship to CTW, Fundação de Amparo à Pesquisa do Estado de São Paulo (FAPESP) (Protocol No. 2010/50973-7, 2010/50294-2 and 2014/50280-2), and Fundação de Amparo ao Ensino e à Pesquisa (FAEP).

\section{Author Contributions}

Claudia Tiemi Wazema: Substantial contribution in the concept and designer of the study; Contribution to data collection; Contribution to manuscript preparation; Contribution to critical revision adding intellectual content.

Victor Hideki Nagatani: Substantial contribution in the concept and designer of the study; Contribution to manuscript preparation; Contribution to critical revision adding intellectual content.

Débora Rodrigues de Souza-Campana: Substantial contribution in the concept and designer of the study; Contribution to data collection; Contribution to manuscript preparation; Contribution to critical revision adding intellectual content.

Fabrício Severo Magalhães: Substantial contribution in the concept the study; contribution to data collection.
Ricardo Sartorello: Substantial contribution in the concept and designer of the study; Contribution to critical revision adding intellectual content.

Maria Santina de Castro Morini: Substantial contribution in the concept and designer of the study; Contribution to data collection; Contribution to manuscript preparation; Contribution to critical revision adding intellectual content.

\section{Conflicts of Interest}

The authors declare no conflicts of interest in the publication of this manuscript.

\section{References}

ANTMAPS. https://antmaps.org/?mode=diversity\&genus=Discothyrea (last access in 25/03/2020).

ANTWEB. https://www.antweb.org/description.do?subfamily=proceratiinae\& genus $=$ discothyrea\&rank $=$ genus (last access in 25/03/2020).

ANTWIKI. https://www.antwiki.org/wiki/Discothyrea (last access in 25/03/2020).

ARCUSA, J.M. \& CICCHINO, A.C. 2017. New locality record of Discothyrea neotropica (Bruch, 1919) (Hymenoptera, Formicidae) for Argentina and remarks on its distribution. Check List 13:635-638.

BACCARO, F.B., FEITOSA, R.M., FERNANDEZ, F., FERNADES, I.O., IZZO, T.J., SOUZA, J.P. \& SOLAR, R. 2015. Guia para os gêneros de formigas do Brasil. Manaus: IMPA, p.388.

BHARTI, H., AKBAR, S.A. \& SINGH, J. 2015. Discothyrea periyarensis sp. n., a new proceratiine ant species (Hymenoptera: Formicidae: Proceratiinae) from India. Causasian Entomol. Bull. 11:121-124.

BORGMEIER, T. 1949. Formigas novas ou pouco conhecidas de Costa Rica e da Argentina. Rev. Bras. Biol. 9:201-210.

BRANDÃO, C.R.F., SILVA, R.R., DELABIE, J.H.C. Formigas (Hymenoptera). 2009. In: PARRA, J.R.P., PANIZZI, A.R., HADDAD, M.L., PANIZZI, A. \& PARRA, J. (Eds.) Bioecologia e nutrição de insetos: base para o manejo integrado de pragas. Embrapa informação tecnológica, DF: Brasília, p.323-369.

BROWN, W.L. 1957. Predation of arthropod eggs by the ant genera Proceratium and Discothyrea. Psyche 64:115-115.

BROWN, W.L. 1958. A review of the ants of New Zealand (Hymenoptera). Acta Hymenopterol. 1:1-50.

CASIMIRO, M.S., SANSEVERO, J.B. \& QUEIROZ, J.M. 2019. What can ants tell us about ecological restoration? A global meta-analysis. Ecol. Indic. 102:593-598. 
CEPTEC-INPE. http://clima1.cptec.inpe.br/estacoes/ (last access in 10/01/2020).

COLOMBO, A.F. \& JOLY, C.A. 2010. Brazilian Atlantic Forest lato sensu: the most ancient Brazilian forest, and a biodiversity hotspot, is highly threatened by climate change. Braz. J. Biol. 70:697-708.

CRIST, T.O. 2009. Biodiversity, species interactions, and functional roles of ants (Hymenoptera: Formicidae) in fragmented landscapes: a review. Myrmecol. News 12:3-13.

CUMMING, G.S. 2011. Spatial resilience: integrating landscape ecology, resilience, and sustainability. Landsc. Ecol. 26:899-909.

DECAËNS, T. 2010. Macroecological patterns in soil communities. Global Ecol. Biogeogr. 19:287-302.

DEJEAN, A. \& DEJEAN, A. 1998. How a ponerine ant acquired the most evolved mode of colony foundation. Insect Soc. 45:343-346.

DEJEAN, A., GRIMAL, A., MALHERBE, M.C. \& SUZZONI, J.P. 1999. From Specialization in spider egg predation to an original nesting mode in a "primitive" ant: a new kind of lestobiosis. Naturwissenschaften 86:133-137.

DELABIE, J.H.C., FEITOSA, R.M., SERRÃO, J.E., MARIANO, C.S.F. \& MAJER, J.D. 2015. As poneromorfas do Brasil, Ilhéus: Bahia. Editora UESC, p.145-162.

EGUCHI, K., BUI, T.V. \& YAMANE, S. 2014. Generic Synopsis of the Formicidae of Vietnam (Insecta: Hymenoptera), Part II - Cerapachyinae, Aenictinae, Dorylinae, Leptanillinae, Amblyoponinae, Ponerinae, Ectatomminae and Proceratiinae. Zootaxa 3860:1-46.

FEITOSA, R.S.M. \& RIBEIRO, A.S. 2005. Mirmecofauna (Hymenoptera, Formicidae) de serapilheira de uma área de Floresta Atlântica no Parque Estadual da Cantareira-São Paulo, Brasil. Biotemas 18:51-71.

FERNANDES, T.T., SILVA, R.R., SOUZA-CAMPANA, D.R., SILVA, O.G.M. \& MORINI, M.S.C. 2019a. Winged ants (Hymenoptera: Formicidae) presence in twigs on the leaf litter of Atlantic Forest. Biota Neotrop. 19(3): http://dx.doi.org/10.1590/1676-0611-bn-2018-0694 (last access in 09/07/2020).

FERNANDES, T.T., DÁTTILO, W., SILVA, R.R., LUNA, P., OLIVEIRA, C.M., MORINI, M.S.C. 2019b. Ant occupation of twigs in the leaf litter of the Atlantic Forest: influence of the environment and external twig structure. Trop. Conserv. Sci. 12:1-9.

FERNANDES, T.T. DÁTTILO, W., SILVA, R.R., LUNA, P., MORINI, M.S.C. 2020. Cohabitation and niche overlap in the occupation of twigs by arthropods in the leaf litter of Brazilian Atlantic Forest. Insectes Soc. https:// doi.org/10.1007/s00040-020-00753-w

FERNÁNDEZ, F. 2003. Introducción a las hormigas de la región neotropical. Instituto de Investigación de Recursos Biológicos Alexander von Humboldt, Bogotá, Colombia.

FIASCHI, P., PIRANI, J.R. 2009. Review of plant biogeographic studies in Brazil. J. Syst. Evol. 47:477-496.

HITA-GARCIA, F., LIEBERMAN, Z., AUDISIO, T.L., LIU, C., \& ECONOMO, E.P. 2019. Revision of the highly specialized ant genus Discothyrea (Hymenoptera: Formicidae) in the Afrotropics with X-Ray Microtomography and 3D Cybertaxonomy. Insect Syst. \& Divers. 3:1-84.

JIMÉNEZ, E., FERNÁNDEZ, F., ARIAS, T.M., \& LOZANO-ZAMBRANO, F.H. 2008. Sistemática, biogeografía y conservación de las hormigas cazadoras de Colombia. Instituto de Investigación de Recursos Biológicos Alexander von Humboldt. Bogotá, Colombia.

JOLY, A.C., METZGER, J.P., TABARELLI, M. 2014. Experiences from the brazilian Atlantic Forest: ecological findings and conservation initiatives. New Phytol. 204:459-473.

KASPARI, M. 1996. Testing resource-based models of patchiness in four neotropical litter ant assemblages. Oikos 76:443-454.

KASPARI, M. \& WEISER, M.D. 1999. The size-grain hypothesis and interspecific. Funct. Ecol. 13:530-538.

KATAYAMA, M. 2013. Predatory behaviours of Discothyrea kamiteta (Proceratiinae) on spider eggs. Asian Myrmecol. 5:121-124.

LASSAU, S.A. \& HOCHULI, D.F. 2004. Effects of habitat complexity on ant assemblages. Ecography 27:157-164.
LIMA-RIBEIRO, M.S. 2008. Efeitos de borda sobre a vegetação e estruturação populacional em fragmentos de Cerradão no Sudoeste Goiano, Brasil. Acta Bot. Bras. 22:535-545.

LINDENMAYER, D., HOBBS, R.J., MONTAGUE-DRAKE, R., ALEXANDRA, J.,BENNETT, A., BURGMAN, M., CALE, P., CALHOUN, A., CRAMER, V.,CULLEN, P., DRISCOLL, D., FAHRIG, L., FISCHER, J., FRANKLIN, J., HAILA, Y., HUNTER, M., GIBBONS, P., LAKE, S., LUCK, G., MACGREGOR, C., MCINTYRE, S., MAC NALLY, R., MILLER, J., MOONEY, H., NOSS, R., POSSINGHAM, H., SAUN-DERS, D., SCHMIEGELOW, F., SCOTT, M., SIMBERLOFF, D., SISK, T., TABOR, G., WIENS, J., WOINARSKI, J. \& ZAVALETA, E. 2008. A checklist for ecological management of landscapes for conservation. Ecol. Lett. 11:78-91.

LÁSZLÓ, Z., RÁKOSY, L. \& TÓTHMÉRÉSZ, B. 2014. Landscape and local variables benefit rare species and common ones differently. J. Insect Conserv. 18:1203-1213

MAGNAGO, L.F.S., ROCHA, M.F., MEYER, L., MARTINS, S.V., MEIRANETO, J.A.A. 2015. Microclimatic conditions at forest edges have significant impacts on vegetation structure in large Atlantic forest fragments. Biodivers. Conserv. 24:2305-2318.

MENTONE, T.O., DINIZ, E.A., MUNHAE, C.D.B., BUENO, O.C. \& MORINI, M.S.C. 2011. Composição da fauna de formigas (Hymenoptera: Formicidae) de serapilheira em florestas semidecídua e de Eucalyptus spp., na região sudeste do Brasil. Biota Neotrop. 11(2): http://www.biotaneotropica.org.br/ v11n2/en/abstract?inventory+bn00511022011. (last access in 20/03/2020).

MORINI, M.S.C., MUNHAE, C.D.B.,LEUNG, R., CANDIANI, D.F. \& VOLTOLINI, J.C. 2007. Ants' communities (Hymenoptera, Formicidae) in fragments of the Atlantic Rain Forest situated in urban areas. Iheringia, Sér. Zool. 97:246-252.

MOREIRA, E.F., BOSCOLO, D. \& VIANA, B.F. 2015. Spatial heterogeneity regulates plant-pollinator networks across multiple landscape scales. PLoS One 10:1-19.

PACHECO, R., SILVA, R.R., MORINI, M.S.C. \& BRANDÃO, C.R. 2009. A comparison of the leaf-litter ant fauna in a secondary Atlantic Forest with an adjacent pine plantation in southeastern Brazil. Neotrop. Entomol. 38:55-65.

QGIS DEVELOPMENT TEAM 2018. QGIS Geographic Information System. Open Source Geospatial Foundation Project.

R CORE TEAM 2019. R: A language and environment for statistical computing. R Foundation for Statistical Computing, Vienna, Austria. URL https:// www.R-project.org/.

RIBAS, C.R., CAMPOS, R.B., SCHMIDT, F.A. \& SOLAR, R.R. 2012. Ants as indicators in Brazil: a review with suggestions to improve the use of ants in environmental monitoring programs. Psyche 2012:1-23.

RIBEIRO, M.C., METZGER, J.P., MARTENSEN, A.C., PONZONI, F.J., HIROTA, M.M. 2009. The Brazilian Atlantic Forest: How much is left, and how is the remaining forest distributed? Implications for conservation. Biol. Conserv. 142:1141-1153.

SANTOS, C.P.S. 2008. Distribuição e diversidade de formigas de serapilheira (Hymenoptera: Formicidae) ao longo de um gradiente elevacional no Parque Estadual da Serra do Mar-Núcleo Picinguaba, São Paulo, Brasil. Tese de Doutorado, Universidade de São Paulo, São Paulo.

SCHOEREDER, J.H., SOBRINHO, T.G., RIBAS, C.R. \& CAMPOS, R.B. 2004. Colonization and extinction of ant communities in a fragmented landscape. Austral Ecol. 29:391-398.

SOSA-CALVO, J. \& LONGINO, J.T. 2007. Subfamilia Proceratiinae. In: JIMÉNEZ, E., FERNÁNDEZ, F., ARIAS, M.T. \& LOZZANO-ZAMBRANO, F.H. (Eds.) Sistemática, Biogeografía y Conservación de las Hormigas Cazadoras de Colombia. Instituto de Investigación de Recursos Biológicos Alexander von Humboldt, Bogotá DC, p.219-237.

SPIESMAN, B.J. \& CUMMING, G.S. 2008. Communities in context: the influences of multiscale environmental variation on local ant community structure. Landsc. Ecol. 23:313-325.

SUGUITURU, S.S., SILVA, R.R., SOUZA, D.R., MUNHAE, C.B. \& MORINI, M.S.C. 2011. Ant community richness and composition across a gradient from Eucalyptus plantations to secondary Atlantic Forest. Biota Neotrop. 11(1): https://doi.org/10.1590/S1676-06032011000100034. (last access on 20/03/2020). 
SUGUiTuRU, S.S., SOUZA, D.R., MUNHAE, C.B. \& MORINI, M.S.C 2013. Diversidade e riqueza de formigas (Hymenoptera: Formicidae) em remanescentes de Mata Atlântica na Bacia Hidrográfica do Alto Tietê, SP. Biota Neotrop. 13(2): http://www.biotaneotropica.org.br/v13n2/en/abstract? inventory+bn00813022013. (last access on 20/03/2020).

SUGUITURU, S.S., MORINI, M.S.C., FEITOSA, R.M. \& SILVA, R.R. 2015 Formigas do Alto Tietê. $1^{\text {a }}$ ed., São Paulo, Bauru: Canal6, p.407-408.

TABARELLI, M., PINTO, L.P., SILVA, J.M.C., HIROTA, M.M. \& BEDÊ, L.C. 2005. Desafios e oportunidades para a conservação da biodiversidade na Mata Atlântica brasileira. Megadiversidade 1:132-138.

VASCONCELOS, H.L. \& DELABIE, J.C.H. 2000. Ground ant communities from central Amazonia Forest fragments. In: AGOSTI, D., MAJER, J., ALONSO, L. \& SCHULTZ, T. (Eds.), Sampling ground dwelling ants: case studies from the world's rain forests. Curtin University School of Environmental of Biology Bulletin, p.59-70.
WAZEMA, C.T., MORINI, M.S.C. \& SOUZA-CAMPANA, D.R. 2019. Diversidade de formigas (Hymenoptera: Formicidae) em um fragmento de Mata Atlântica no município de Mogi das Cruzes (SP). Revista Científica UMC 4:1-12.

XU, Z.H., BURWELL, C.J. \& NAKAMURA, A. 2014. Two new species of the proceratiine ant genus Discothyrea Roger from Yunnan, China, with a key to the known Oriental species. Asian Myrmecol. 6:33-41.

YATES, M. \& ANDREW, N.R. 2011. Comparison of ant community composition across different alnd-use types: assessing morphological traits with more common methods. Aust. J. Entomol. 50:118-124.

ZACHARIAS, M. \& DHARMA RAJAN, P. 2004. Discothyrea sringerensis (Hymenoptera: Formicidae) a new ant species from India. Zootaxa 484:1-4.

Received: 07/05/2020

Revised: $31 / 07 / 2020$

Accepted: $18 / 08 / 2020$

Published online: 18/09/2020 